\title{
The Transformation of Teacher and Student Roles in the European Higher Education Area
}

\author{
María Luisa Pérez Cañado \\ University of Jaén/Department of English Philology, Jaén, Spain \\ Email: mlperez@ujaen.es
}

\begin{abstract}
This article illustrates how the creation of the European Higher Education Area is subverting the traditional roles of students and teachers in tertiary language education. It portrays the shift which has been made from the previous teacher-directed, lecture-based system which has traditionally prevailed in European Higher Education to the present-day student-centered, meaning-based model. The new learning modalities and teacher and student roles to which the European Higher Education Area has given rise are all practically examined, using five pedagogical innovation projects as a backdrop. Evidence is then furnished by presenting the results of a qualitative study on the attitudes which student-centered learning is generating in the participating student body. A survey administered in June 2006, 2007, and 2008 to the regular participants in the pedagogical innovation projects yields very positive outcomes for a tertiary education system which is centered on the student and testifies to the progressive consolidation of the new credit system at the University of Jaén in Spain.
\end{abstract}

Index Terms-European Higher Education Area, European Credit Transfer System, student-centered learning, teacher and student roles, English language teaching, student attitudes

\section{INTRODUCTION}

A period of immense upheaval in European Higher Education (HE) has been initiated by the so-called Bologna Process. The last decade has seen the introduction of significant changes in the landscape of tertiary education in Europe through the creation of the European Higher Education Area (EHEA), which has been channeled via a set of official documents, declarations, and communiqués, from the Lisbon (1998) and Bologna (1999) Declarations to the most recent London Communiqué (2007).

It is in the language teaching arena that this reorientation and reform perhaps acquire a sharper relief, as the application of the new European Credit Transfer System (ECTS) is involving profound changes which are affecting all levels of the curriculum. Objectives are now formulated in terms of key competencies to be acquired; a methodological "plurality" (CIDUA, 2005: 26) which incorporates the latest trends in language teaching is propounded; learning modalities now involve a vast gamut of classroom organizations; ICT acquires a heightened role within materials and resources; and evaluation is more personalized, formative, and transparent. This marked innovation is, however, particularly conspicuous in the new teacher and student roles advocated by the new credit system.

Sure enough, in making the shift to the practical application of the European convergence process, the official documents (e.g. Glasgow Declaration, 2005; Lisbon Declaration, 2007) explicitly state that the promotion of studentcentered learning should be a key goal and that a stronger student focus should guide curricular reorientations. This is a particularly lofty goal, considering that European HE has traditionally operated with a transmission of knowledge model based on ex cathedra lecturing (Tudor, 2007). The onus is now on successful learning rather than on the teaching provided (McLaren et al., 2005: 27). There is a concern for equipping students not only with cognitive knowledge, but with a set of skills, attitudes, and values - competencies - which they need for their successful incorporation to the labor market. The link to the outside world, bearing in mind potential employers' needs (Berlin Communiqué, 2005), is thus made explicit. Lifelong learning (Mackiewicz, 2002) also comes to the fore in order to ensure students are armed with the tools they need to continue learning throughout their lives, transferring what they have acquired to different contexts (Perkins and Salomon, 2001: 370).

The aim of this article is to illustrate how these theoretical postulations on student-centered learning included in official European documents are being implemented in practice in a European HE context. In particular, they will be presented within the framework of an English language teaching (ELT) subject - Inglés Instrumental Intermedio - at the University of Jaén in Spain, and grounded on five pedagogical innovation projects which have developed within it. The new student and teacher roles to which the piloting of the ECTS has given rise will be illustrated against the backdrop of these projects, and data will be provided on the students' attitudes towards their more active and participative role in the new European credit system. 


\section{Contextualization of THE SubJect, THE Projects, AND THE Study}

There is no better angle from which to examine the application of the theoretical underpinnings of the EHEA to ELT than the subject of Inglés Instrumental Intermedio, given its purely instrumental and linguistic character. It is a 15-credit core subject in the degree of English Philology at the University of Jaén, which students must obligatorily study in their first year at college. Its aim, as explicitly stated in the B.O.E (Boletín Oficial del Estado) is "Formación práctica a nivel intermedio en las cuatro destrezas comunicativas, dominio del léxico y del uso del inglés. Estudio del sistema vocálico y consonántico" (B.O.E. de 17 de octubre de 2000). In other words, it provides students with extensive practice in the four language skills (reading, writing, listening, and speaking) and with overt instruction in grammatical aspects (from verb tenses to the passive voice or reported speech), lexical competence (collocations, idiomatic expressions, phrasal verbs, or semantic fields related to such general topics as family, health, or technology), functions (e.g., agreeing and disagreeing, expressing opinions, or giving advice), and phonetics (through an introduction to the English vowel and consonant system). It is one of the only two subjects in the degree which focuses purely on the use of English; hence its importance.

Prior to the implementation of the ECTS scheme at the University of Jaén, the subject of Inglés Instrumental Intermedio was taught in what Norris and Ortega (2000: 420, following Long, 1991, 1997, and Long and Robinson, 1998) would characterize as a focus on form approach, which integrates forms and meaning, capitalizing on interventions that draw learners' attention to formal properties of linguistic features in the context of meaningful communication. In teaching especially the oral skills, Communicative Language Teaching (cf. Brown, 1994 or Richards and Rodgers, 2001) was the prime approach, as classroom language learning was linked with real-life communication outside its confines, and authentic samples of language and discourse or contextualized chunks rather than discrete items were employed. All in all, an explicit (Sharwood-Smith, 1981; Stern, 1992), intentional (Schmidt, 1994; Hulstijn, 2001), or instructed (Ellis, 1985, 1994) methodology was followed to foster grammatical and lexical development. A main coursebook was employed, complemented with certain additional materials, and lockstep work in contact sessions with the teaching staff, where paper and pencil exercises were done and corrected, was the norm.

However, since the ECTS scheme began to be piloted in the degree of English Philology in the academic year 20042005, the ELT panorama in the subject has substantially changed. The different philosophy which the European Higher Education Area has at all levels of the curriculum (from objectives through evaluation procedures) has spurred us to conceptualize, coordinate, and undertake five pedagogical innovation projects within the subject, all in the past four academic years.

These pedagogical innovation projects have involved the use of Computer Assisted Language Learning (CALL), as understood in the inclusive sense (Levy and Hubbard, 2005: 148), and Data-Driven Learning (DDL) (Johns, 2002) to raise awareness of and remediate the writing weaknesses of our students (2004-2005); setting up a virtual learning environment (VLE) through the ILIAS Platform for the subject, where the undergraduates can download the material they need for the subject, communicate through a forum, or post their recommendations through a virtual "Suggestions Box" (2006-2007); establishing a telecollaboration exchange with the Southern Methodist University of Dallas, whereby each Jaén freshman has a Dallas tutor assigned with whom s/he communicates on a weekly basis and carries out a structured set of ELT tasks via the Blackboard on-line platform (2006-2007); designing a bank of materials for the development of lexical competence through sitcoms and TV series in a virtual learning environment (2006-2007); and setting up a peer tutoring project between English Philology freshmen and sophomores at our university to foster generic cross-curricular competencies (2007-2008).

The projects have allowed the incorporation of a multiplicity of teaching approaches which have favored the transition from information- to meaning-based education; from a "bulimic" learning where the students merely regurgitate what they have learned, to a more critical learning that sticks. That is, they have promoted what McGonigal (2005) terms "teaching for transformation". These approximations to language teaching have included autonomous, lifelong, and cooperative learning, CALL and blended learning, the Lexical Approach, task-based learning, Neurolinguistic Programming, and Multiple Intelligence Theory (cf. Author and Ware, 2009). They have also diversified evaluation procedures and techniques, now accounting for $60 \%$ of the final grade, thus attaching greater importance to on-going assessment (Madrid and Author, 2004) and to the amount of individual, private, or personal work put in by the student (Ron Vaz et al., 2006).

However, how have these novel teaching initiatives specifically affected student and teacher roles? The next three sections provide concrete examples.

\section{LEARNING MODALITIES}

To begin with, the previous teacher-directed, lecture-based system, which was essentially built on lockstep theoretical sessions with the whole class, is now only one more type of learning modality which the students engage in. Numerous authors (Casas Gómez and Márquez Fernández, 2004; De Miguel Díaz, 2005, 2006; Giménez de la Peña and López Gutiérrez, 2006; Ron Vaz et al., 2006; Arias Blanco, 2007) testify to the vast gamut of classroom organizations to which the new credit system has led. Amongst them, lectures or conferences, theoretical classes, practical sessions, seminars and workshops, group and individual work, or tutorials are all mentioned. 
All these learning modalities can be discerned in the subject of Inglés Instrumental Intermedio and can thus be easily and effectively applied to language teaching. To begin with, theoretical contact sessions with the teaching staff in large groups have been reduced to two hours a week and are primarily employed to introduce, in a global manner, the concepts and notions of grammar, vocabulary, and the skills which are then explored from a practical point of view in the seminars and practical sessions. In turn, group work is fostered in the debates and role-plays which take place on a more regular basis in the new credit system. Individual work or independent/private study, made possible in the new system thanks to its consideration of out-of-class student work in the conception of credits, has also gained in importance for such activities as the telecollaboration exchange, the preparation and delivery of oral presentations, or the completion of lexical tasks through the online virtual platform. Practical sessions subdivide the whole class into two subgroups for work on the oral skills, and seminars take place once a week in reduced groups of five to eight students with a clearly practical slant. These seminars, following to a large extent the methodological recommendations of Casas Gómez and Márquez Fernández (2004), involve such varied activities as group debates, role plays, watching and commenting on popular sitcoms in DVD format, doing specialized reading activities, carrying out personalized correction of compositions and awareness-raising of the main mistakes discerned, conference attendance and summaries, personalized work on pronunciation aspects, "coffee and talk" sessions with students from different English-speaking backgrounds (The United States, Canada, Scotland, and England), or the incorporation of new technologies into language teaching (e.g., through the telecollaboration project or the use of DDL and VLE).

Finally, individual tutorials are used for reinforcement purposes, problem resolution, personalized work, or followup to the development of the telecollaboration, peer tutoring, or VLE experiences. In this sense, they combine what Del Rincón Igea (2000) terms tutoría de enseñanza-aprendizaje (for teaching-learning purposes) and tutoría personalizada (to work on individual problems and personal approximation to and interpretation of the contents of the subject).

These diverse learning arrangements have been viewed in a positive light by the students (cf. Section 6), since they seem to be benefiting from them, as Taibi (2006) also documents with respect to individual tutorials.

\section{TEACHER ROLES}

These diverse learning arrangements have involved, on the one hand, a noteworthy change in the university lecturer's role, as numerous authors document (e.g., Durán et al., 2006 or Ron Vaz et al., 2006). There is thus a "nueva y necesaria reformulación del papel docente del profesor universitario"1 (Ron Vaz et al., 2006, 2).

In the Spanish university system, the teacher has traditionally been conceived as a director or orchestrator, instructor or expert transmitter of knowledge, and as a source of information or "pozo de ciencia", in Medina's (2004: 44) words. As Pozuelos et al. (2006: 2) put it,

La actual docencia universitaria se encuentra más centrada en la enseñanza que en el aprendizaje, y la percepción más generalizada sobre la función del profesor en este contexto es la de un experto en su materia cuyo rol consiste en transmitir conocimientos relevantes y actualizados a estudiantes que deben ser capaces de memorizarlos $y$ reproducirlos. ${ }^{3}$

At present, while maintaining these roles in the more traditional lockstep contact sessions of Inglés Instrumental Intermedio, the ELT teacher must also be prepared to assume new ones (McLaren et al., 2005; Martínez Lirola, 2007). To begin with, we are now motivators, dynamizers, stimulators, and creators of a positive classroom atmosphere through the numerous pedagogical innovation projects we are putting into practice in the classroom (cf. Section 2). We become counsellors, tutors, and advisers in the personalized tutorials (cf. Section 3). We act as guides, helpers, facilitators, and resources in the seminar activities and in providing the students with references and guidelines for their autonomous work. We turn into observers and participants in the learners' debates and Power Point presentations on grammar. We plan, monitor, and supervise the on-line telecollaboration exchange, peer-tutoring project, and VLE lexical activities. We, of course, assess the outcomes of both the formative and summative work. We also turn into investigators of the findings yielded by our pedagogical innovation projects via the empirical studies which accompany them. And we equally need to engage in a greater collaboration, communication, and transparency (Giménez de la Peña and López Gutiérrez, 2006; Miedes Ugarte and Galán García, 2006; Pozuelos et al., 2006) with our colleagues in setting up joint projects (e.g., with Inglés Instrumental Avanzado in the peer tutoring experience) and in ensuring smooth transitions between related subjects. In this sense, Giménez de la Peña and López Gutiérrez (2006: 10) stress that "[...] una de las innovaciones que plantea el nuevo modelo docente es la apertura a la colaboración entre profesores y asignaturas para favorecer la comprensión de distintos puntos de vista o la intervención en diferentes ambientes." 4

\footnotetext{
1 "a new and necessary reformulation of the university professor's teaching role" (our translation)

2 "a well of science" (our translation)

3 "Present-day university teaching centers more on teaching than on learning, and the most generalized perception of the teacher's role in this context is that of expert in his/her subject who transmits relevant and updated knowledge to students who must memorize and reproduce it." (Our translation)

4 "one of the innovations of the new teaching model is the openness to collaborate between teachers and subjects in order to foster the understanding of diverse points of view or intervention in different environments" (our translation)
} 
All in all, the university teacher - with Inglés Instrumental Intermedio being no exception - assumes a crucial role as catalyst of change (Miedes Ugarte and Galán García, 2006). This, not surprisingly, is entailing a greater amount of work, preparation, dedication, and change of mindset on the part of the teacher (Ron Vaz et al., 2006), which is not being achieved without difficulty (Jiménez Reina et al., 2006) and which sometimes verges on overload (Martos Montes et al., 2006; Pozuelos et al., 2006). In our specific case, the elaboration of original material (e.g. in the VLE project), the set-up, monitoring, and evaluation of the telecollaboration and peer-tutoring experiences, or the investigations undertaken to determine the effects of our innovation are certainly involving a noteworthy effort on our part, though an undoubtedly worthwhile one when we examine the results of our endeavour (cf. Section 6).

\section{STUdENT Roles}

A similar difficulty in the transformation of student roles is being perceived in the new system (e.g. Díaz Negrillo and Valera Hernández, 2006), especially when it concerns freshmen (as is the case of Inglés Instrumental Intermedio), who have to learn to take responsibility for their own learning and to undergo an academic and personal maturation process. They are no longer passive recipients or empty vessels who accumulate and repeat the information received (Domingo et al., 2007), but, rather, the protagonists of the learning process. In Martínez Lirola's (2007: 36) words, “[ [...] el alumno, estimulado por la voluntad interactiva del profesor, ha de participar activamente en el aula, tomando las riendas cuando el profesor o la actividad se lo exija. Debe cambiar ciertos hábitos acomodaticios y pasivos, convencerse de que es, en realidad, el centro del proceso y afrontar con decisión ese reto." 5

This learner-centered education has induced significant changes for the studentship, which, again, are clearly felt in Inglés Instrumental Intermedio. The learners are more autonomous and independent (McLaren et al., 2005; Ron Vaz et al., 2006; Martínez Lirola, 2007) (e.g., through the telecollaboration tasks and lexical activities they have to complete in their personal work hours); more active and participative in classroom activities (Giménez de la Peña and López Gutiérrez, 2006) (e.g., by means of the "jury" system established to evaluate their classmates' presentations or the "coffee and talk" sessions organized with native English speakers); more creative (Martínez Lirola, 2007; Domingo et al., 2007; Author, 2009) (as can be observed, e.g., in the way they design their oral presentations); and more involved in the decision-making process (Taibi, 2006) (e.g., through the "Suggestions Box" created on-line for them to post their suggestions for the subject or through our choice of DVDs for the VLE project based on their preferences). This clearly leads to an increased personalization of the learning process (Ron Vaz et al., 2006) and to a heightened contact and closer relationship between teacher and student (Martos Montes et al., 2006), as is evinced in some of the e-mails received from our students (cf. Fig. 1). According to Martos Montes et al. (2006) and Felder and Brent (1996), all these changes are also favoring more significant learning, greater retention of knowledge, and processing at a deeper level on the part of the student.

Dear Marisa,

Hi!! How's that going? I hope good.[...]

Thank you for the breakfast on Wednesday!!!! That was very kind of you!!! I had a lot of fun and met a very nice girl. We were invited to a birthday party - Jamie's 21st birthday - and Loli, Elena and me joined. We met a lot of people - most of them English - and had a great night. I have nothing

else to tell you. $\mathrm{C}$ u tomorrow in class!

María Jesús

Figure 1. Extract from a sample e-mail from an Inglés Instrumental Intermedio student.

\section{The EVIDENCE: Results FROM THE QUALITATIVE STUDY}

It follows from the foregoing that the application of the ECTS is generating new teacher and student roles and learning modalities which favour the interaction of both agents in the teaching-learning process. However, what kinds of attitudes is the new system generating in the participating student body? How does the latter feel about taking centerstage in the new system? A survey administered in June 2006, 2007, and 2008 to the regular participants in the pedagogical innovation projects (15 in 2007 and 10 in 2007 and 2008) has allowed us to answer these questions.

\footnotetext{
5 "The student, stimulated by the teacher's interactive will, must participate actively in the classroom, taking control when the teacher or the activity require it. S/he must change certain passive habits, in the conviction that $\mathrm{s} / \mathrm{he}$ is, in fact, the center of the process, facing that challenge decisively." (Our translation)
} 


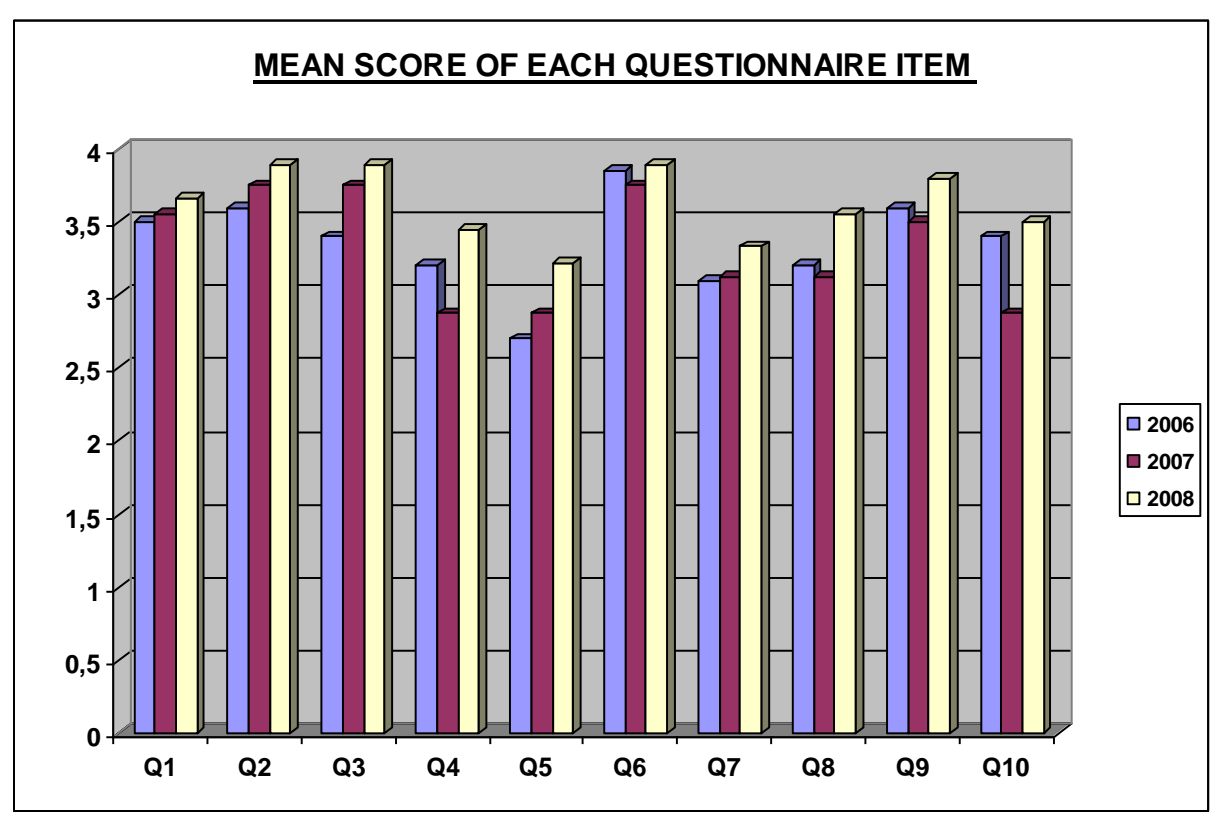

Figure 2. Mean score of each questionnaire item in the three years of ECTS piloting.

Overall, in the three years of piloting of the ECTS experience, the sample values the learning modalities, timetabling, evaluation, and teacher's commitment to the new credit system extremely positively, as mean scores between 3 and 4 (on a 4-point Likert-type scale) are obtained for the items considered in the survey (cf. Fig.2).

As the pilot experience has consolidated in the subject, the students have seen an increasingly appreciable difference between the methodology followed in the lockstep contact sessions and the seminars (item 1), and have increasingly valued the activities in the seminars - considering they offer better conditions for learning (item 2) - and the use of group work and individual tutorials, which they hold have a positive repercussion on learning outcomes (item 5). This same trend of growing appreciation discerned for the learning modalities also applies to item 7, where the learners view the new system as optimizing learning outcomes, each year more than the last.

Items 4 and 10, while presenting an important positive leap in students' attitudes from the first to the third year considered, also evince a slump in the 2007 cohort's attitudes. Both questions probe the freshmen's opinions on the amount of individual or private work put in by the student. It seems that, in the second year of piloting considered, the students do not see this amount of work as adequate or proportional (item 4) as in the other two academic years, and, thus, tend to prefer a system which is based on traditional contact sessions with the teaching staff (item 10). This finding is interesting and perhaps reflects the different learning styles of the 2007 students. It also accords with the outcomes of a quasi-experimental quantitative study we conducted that year to determine the possible differential effects of the ECTS as compared to the traditional Spanish university method. When considering the intervening variable of performance on the university entrance exam, we ascertained the students with the poorest results in this exam (Ds) appeared to work better within the traditional credit system, based more on lockstep teaching and less on independent work on the part of the student. Madrid \& Hughes (forthcoming) have also recently come across the same skepticism towards non-presential sessions on the part of the students studying FL Teacher Training within the ECTS at the University of Granada. Thy found many learners did not agree with reduced in-class time and expressed their desire to have more presential sessions in order to be able to complete all the tasks assigned by teachers.

Another curious finding affects item 5, which explores whether the ECTS requires an overwhelming effort on the part of the sample. Although this item obtains the lowest score on all three years - something positive for the subject -, it is undeniably higher in 2008. This last group has been the one to value the ECTS experience most positively on all the questions considered, yet they also acknowledge it has required substantial - verging on excessive - commitment and work on their part.

Evaluation (item 8) is quite positively valued in all three years: the students believe that the evaluation criteria in the new credit system are more precise and realistic in reflecting the real workload of the learner. However, the most highly ranked questions are 6 and 9. The highest scores are invariably obtained for item 6 - the cohort sees the teacher as extremely committed to the new methodology involved in the ECTS -, and item 9 reveals that the students prefer a tertiary education system which is centered on the student.

\section{DISCUSSION}

The outcomes yielded by this qualitative study have been very encouraging. The attitudes generated in the participating student body by the novel learning models and teacher and student roles involved in the new credit system have been extremely positive, and, in general, increasingly so as the years of piloting have consolidated the ECTS 
experience. The student-centered learning to which this new system has led thus seems to be generating high student satisfaction, something which accords with Felder and Brent's (1996) findings.

These results are particularly heartening when we consider the outcomes of the qualitative study which was conducted by García García (2005) after the first year of ECTS pilot experience in the degree of English Philology at the University of Jaén. Both students and lecturers considered the new system implied no change or improvement in learning modalities, and students in particular felt that lecturers were not really committed to the proper development of the project. After three further years of piloting, the situation has changed dramatically, and the findings of our survey provide testimony to the fact that the major bumps along the road to student-centered learning have been smoothed.

\section{CONCLUSION}

While countries like the U.S. have a long tradition in student-centered instruction, continental Europe has always followed a more knowledge-oriented paradigm in tertiary education. The situation is - thankfully - now changing, fuelled by the creation of the EHEA, which is acting as a powerful lever for reform.

This article has portrayed how the theoretical underpinnings of the EHEA and its new credit system - the ECTS - are being practically implemented in the language teaching arena in HE. In particular, it has focused on teacher and student roles, illustrating how they have been subverted through the implementation of five pedagogical innovation projects within the piloting of the ECTS at the University of Jaén. The attitudes which this reorientation is generating in the participating student body have also been examined via a qualitative study conducted in the past three academic years (2006, 2007, 2008), and which has revealed high student satisfaction.

There are still, undoubtedly, further adjustments to make and resilience to overcome in making the shift from an information- to a meaning-based tertiary education which centers on the student. After all, as Schechtman and Koser (2008: 312) rightly point out, "Transformations will not be easy". However, making the transition to student-centered learning holds great promise, and our experience and outcomes allows us to maintain a definitely positive outlook on it. As Felder and Brent put it (1996: 47), "it may take an effort to get there, but it is an effort well worth making".

\section{REFERENCES}

[1] Arias Blanco, J. M. (2007). Orientaciones para el cambio metodológico. In Actas de las Jornadas Nacionales de Intercambio de Experiencias Piloto de Implantación de Metodologías ECTS. Badajoz: Servicio de Publicaciones de la Universidad de Extremadura.

[2] Author. (2009). The European Credit Transfer System: Enhancing creativity in teachers and students. Humanising Language Teaching 11.1. http://www.hltmag.co.uk/feb09/mart03.htm (accessed 15/01/2010).

[3] Author \& P. D. Ware (2009). Why CMC and VLE are especially suited to the ECTS: The case of telecollaboration in English Studies. In Author (ed.), English Language Teaching in the European Credit Transfer System: Facing the challenge. Frankfurt am Main: Peter Lang, 111-150.

[4] Brown, H. D. (1994). Teaching by principles. An interactive approach to language pedagogy. Englewood Cliffs: Prentice Hall Regents.

[5] Casas Gómez, M. \& R. Márquez Fernández (2004). El sistema de créditos europeos. Su aplicación práctica a la titulación de "Lingüística" de la Universidad de Cádiz. Cádiz: Servicio de Publicaciones de la Universidad de Cádiz.

[6] CIDUA. (2005). Informe sobre la innovación de la docencia en las universidades andaluzas. Sevilla: Consejería de Educación, Junta de Andalucía. http://www.uca.es/web/estudios/innovacion/ficheros/informeinnovacinjuntaabril2005.doc (accessed 15/01/2010).

[7] De Miguel Díaz, M. (ed.) (2005). Modalidades de enseñanza centradas en el desarrollo de competencias. Orientaciones para promover el cambio en el marco del EEES. Oviedo: Universidad de Oviedo.

[8] De Miguel Díaz, M. (ed.) (2006). Metodologías de enseñanza y aprendizaje para el desarrollo de competencias. Orientaciones para el profesorado universitario ante el Espacio Europeo de Educación Superior. Madrid: Alianza Editorial.

[9] Del Rincón Igea, B. (2000). Tutorías personalizadas en la universidad. Cuenca: Ediciones de la Universidad de Castilla-La Mancha.

[10] Díaz Negrillo, A. \& S. Valera Hernández (2006). Propuestas docentes para la Enseñanza en Línea de la Lengua Inglesa I. In Actas de las Jornadas de Trabajo sobre Experiencias Piloto de Implantación del Crédito Europeo en las Universidades Andaluzas. Cádiz: Universidad de Cádiz.

[11] Domingo, A., A. Chiloeches, \& V. García (2007). Un paradigma cliente-empresa como método docente. In Actas de las Jornadas Nacionales de Intercambio de Experiencias Piloto de Implantación de Metodologías ECTS. Badajoz: Servicio de Publicaciones de la Universidad de Extremadura.

[12] Durán, M. A., J. L. Peralta, C. Gallego, \& F. M. Montalbán. (2006). Análisis de una encuesta de evaluación de la experiencia piloto de implantación del crédito europeo en las titulaciones de Relaciones Laborales y Trabajo Social. In Actas de las Jornadas de Trabajo sobre Experiencias Piloto de Implantación del Crédito Europeo en las Universidades Andaluzas. Cádiz: Universidad de Cádiz.

[13] Ellis, R. (1985). Understanding second language acquisition. Oxford: Oxford University Press.

[14] Ellis, R. (1994). The study of second language acquisition. Oxford: Oxford University Press.

[15] European Ministers of Education. (1999). The Bologna Declaration. http://www.bologna-bergen2005.no/Docs/00-Main_doc/ 990719BOLOGNA_DECLARATION.PDF (accessed 15/01/2010).

[16] European Ministers Responsible for Higher Education. (2003). Realising the European Higher Education Area. Communiqué of the Conference of Ministers responsible for Higher Education in Berlin on $19^{\text {th }}$ September 2003. http://www.eua. 
be/fileadmin/user_upload/files/EUA1_documents/OFFDOC_BP_Berlin_communique_final.1066741468366.pdf （accessed 15/01/2010).

[17] European Ministers Responsible for Higher Education. (2007). London Communiqué. Towards the European Higher Education Area: Responding to Challenges in a Globalised World. http:// www.cicic.ca/docs/bologna/2007LondonCommunique.en.pdf (accessed 15/01/2010).

[18] European University Association. (2005). Glasgow Declaration - Strong Universities for a Strong Europe. http://www.eua.be/ fileadmin/user_upload/files/EUA1_documents/Glasgow_Declaration.1114612714258.pdf (accessed 15/01/2010).

[19] European University Association. (2007). Lisbon Declaration - Europe's universities beyond 2010: Diversity with a common purpose. http://www.eua.be/fileadmin/user_upload/files/Lisbon_Convention/Lisbon_Declaration.pdf (accessed 15/01/2010).

[20] Felder, R.M. \& R. Brent (1996). Navigating the bumpy road to student-centered instruction. College Teaching 44, 43-47.

[21] García García, L. (2005). European Higher Education Area at the University of Jaén. First steps towards a common European Higher Education and Research Space. Invited talk given at the University of Leeds.

[22] Giménez de la Peña, A. \& F. López Gutiérrez (2006). La actividad docente en el modelo ECTS. In Actas de las Jornadas de Trabajo sobre Experiencias Piloto de Implantación del Crédito Europeo en las Universidades Andaluzas. Cádiz: Universidad de Cádiz.

[23] Hulstijn, J. H. (2001). Intentional and incidental second language vocabulary learning: A reappraisal of elaboration, rehearsal and automaticity. In P. Robinson (ed.), Cognition and second language instruction. Cambridge: Cambridge University Press.

[24] Jiménez Reina, L., J. Peña Amaro, I. Jimena Medina, \& F. Labella Quesada (2006). Reflexión desde el punto de vista del profesorado sobre la implantación del sistema ECTS en la Licenciatura de Medicina de la Universidad de Córdoba. In Actas de las Jornadas de Trabajo sobre Experiencias Piloto de Implantación del Crédito Europeo en las Universidades Andaluzas. Cádiz: Universidad de Cádiz.

[25] Johns, T. (2002). Data-driven learning: the perpetual challenge. In B. Ketterman \& G. Marko (eds.), Teaching and learning by doing corpus analysis. Proceedings of the Fourth International Conference on Teaching and Language Corpora, Graz 19-24 July 2000. Amsterdam and New York: Rodopi.

[26] Levy, M., \& P. Hubbard (2005). Why call call "CALL"? Computer Assisted Language Learning 18.3, 143-149.

[27] Mackiewicz, W. (2002). Lifelong foreign language learning. Paper presented at the European Seminar on Foreign Language Learning Needs in Education Systems, 5-7 May, in Valencia, Spain.

[28] Madrid Fernández, D. \& Author (2004). Evaluation. In. Madrid and N. McLaren (eds.), TEFL in Primary Education. Granada: Editorial Universidad de Granada.

[29] Madrid, D. \& S. Hughes (2009). The implementation of the European credit in initial foreign language teacher training. In Author (ed.), English language teaching in the European Credit Transfer System: Facing the challenge. Frankfurt am Main: Peter Lang.

[30] Martínez Lirola, M. (2007). El nuevo papel del profesor universitario de lenguas extranjeras en el proceso de convergencia europea y su relación con la interacción, la tutoría y el aprendizaje autónomo. Porta Linguarum 7, 31-43.

[31] Martos Montes, R., M. D. Escarabajal Arrieta, M. A. Agüero Zapata \& A. R. Ortega Martínez. (2006). Psicología en la Universidad de Jaén ante el reto del EEES. In Actas de las Jornadas de Trabajo sobre Experiencias Piloto de Implantación del Crédito Europeo en las Universidades Andaluzas. Cádiz: Universidad de Cádiz.

[32] McGonigal, K. (2005). Teaching for transformation. Speaking of Teaching 14.2. http://ctl.stanford.edu/Newsletter/ (accessed $15 / 01 / 2010)$.

[33] McLaren, N., D. Madrid, \& A. Bueno (eds.) (2005). TEFL in secondary education. Granada: Editorial Universidad de Granada.

[34] Medina, J. R. (2004). Los futuros profesores que las universidades demandan. In F. Michavila \& J. Martínez (eds.), La profesión de profesor de universidad. Madrid: Cátedra UNESCO de Gestión y Política Universitaria / Conserjería de Educación de la Comunidad de Madrid.

[35] Miedes Ugarte, B. \& A. Galán García (2006). La aplicación del ECTS en Relaciones Laborales: Un atisbo de los cambios necesarios para alcanzar la convergencia. In Actas de las Jornadas de Trabajo sobre Experiencias Piloto de Implantación del Crédito Europeo en las Universidades Andaluzas. Cádiz: Universidad de Cádiz.

[36] Norris, J. M. \& L. Ortega (2000). Effectiveness of L2 instruction: A research synthesis and quantitative meta-analysis. Language Learning 50.3, 471-528.

[37] Perkins, D. \& G. Salomon (2001). Teaching for transfer. In A. L. Costa (ed.), Developing minds. A resource book for teaching thinking. Alexandria, VA: Association for Supervision and Curriculum Development.

[38] Pozuelos, F. J., A. Conde, P. Alonso, R. Cruz, \& J. M. Rodríguez (2006). La colaboración docente como marco para el desarrollo de la experiencia piloto ECTS de la Titulación de Psicología. In Actas de las Jornadas de Trabajo sobre Experiencias Piloto de Implantación del Crédito Europeo en las Universidades Andaluzas. Cádiz: Universidad de Cádiz.

[39] Richards, J. C. \& T. S. Rodgers (2001). Approaches and methods in language teaching. Cambridge: Cambridge University Press.

[40] Ron Vaz, P., E. Fernández Sánchez, \& J. M. Nieto García (2006). Algunas reflexiones sobre la aplicación del crédito europeo en la Licenciatura de Filología Inglesa en las universidades de Andalucía (Córdoba, Huelva y Jaén). In Actas de las Jornadas de Trabajo sobre Experiencias Piloto de Implantación del Crédito Europeo en las Universidades Andaluzas. Cádiz: Universidad de Cádiz.

[41] Schechtman, R. R. \& J. Koser (2008). Foreign languages and higher education: A pragmatic approach to change. The Modern Language Journal 92.ii, 309-312.

[42] Schmidt, R. (1994). Implicit learning and the cognitive unconscious: Of artificial grammars and SLA. In N. C.Ellis (ed.), Implicit and explicit learning of languages. London: Academic Press.

[43] Sharwood-Smith, M. A. (1981). Consciousness-raising and the second language learner. Applied Linguistics 11.2, 159-168.

[44] Stern, H. H. (1992). Issues and options in language teaching. Oxford: Oxford University Press.

[45] Taibi, M. (2006). Reconsidering tutorials and student-lecturer power relationships in language subjects. Porta Linguarum 6, 33-39. 
[46] Tudor, I. (2007). The language challenge for higher education institutions in Europe, and the specific case of CLIL. Paper presented at El multilingüisme de las universitats en l'Espai Europeu d'Educació Superior, in Barcelona, Spain.

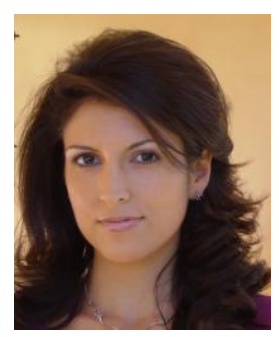

María Luisa Pérez Cañado is Associate Professor at the Department of English Philology of the University of Jáen, Spain, where she is also Vicedean of the Faculty of Humanities and Education.

Her research interests are in Applied Linguistics, English for Specific Purposes, and the intercultural component in language teaching. Her work has appeared in a notable number of scholarly journals and edited volumes published by Elsevier, Peter Lang, Multilingual Matters, Wiley-Blackwell, Routledge, or John Benjamins, among others. She is also author of four books on the interface of second language acquisition and second language teaching, co-author of an instructional method for the teaching of Spanish orthography and written composition in Spain and Mexico, and editor of three books and one ELT journal. She has currently edited the first monograph in Europe on the adaptation of English language teaching to the European Credit Transfer System (Peter Lang; Linguistic Insights Series) and has coordinated three governmentally-funded research projects on this topic.

Dr. Pérez Cañado has been serving as reviewer for ELIA, The Grove and Reading and Writing, and has taught and lectured in Belgium, Poland, Germany, Portugal, Ireland, England, Mexico, The United States, and all over Spain. She is in charge of the programme for the implementation of the European Credit System in English Philology at the University of Jaén and has recently been granted the Ben Massey Award for the quality of her scholarly contributions regarding issues that make a difference in higher education. 